\title{
Traktör İmalatında Çok Kriterli Karar Verme Yöntemleri ile Tedarikçi Seçimi
}

\author{
Tijen Över Özçelik ${ }^{1}$, Sila Azer Eryılmaz ${ }^{2}$ \\ ${ }^{1}$ Sakarya Üniversitesi, Mühendislik Fakültesi, Endüstri Bölümü, Sakarya, Türkiye (ORCID: 0000-0002-9614-8119) \\ 2 Endüstri Mühendisi, KEAN- Cell of Altrenative Youth Activities, (ORCID: 0000-0003-0947-2963)
}

(Bu yayın HORA 2019 kongresinde sözlü olarak sunulmuştur.)

(İlk Geliş Tarihi 10 Temmuz 2019 ve Kabul Tarihi 22 Ekim 2019)

(DOI: $10.31590 /$ ejosat.590418)

\begin{abstract}
ATIF/REFERENCE: Över Özçelik, T. \& Eryılmaz, S. A. (2019). Traktör İmalatında Çok Kriterli Karar Verme Yöntemleri ile Tedarikçi Seçimi. Avrupa Bilim ve Teknoloji Dergisi, (Özel Sayı), 498-512.

$\ddot{O} \mathbf{z}$

İşletmeler üretim faaliyetlerini sürdürebilmek için birçok tedarikçi ile çalışmak ve sürekli olarak karar vermek durumundadır. İşletmeler için verilmesi gereken en önemli kararlardan biride tedarikçi seçimidir. Satın almanın doğru, hızlı ve en düşük maliyetle gerçekleştirilmesi işletmenin rekabet gücü açısından önemlidir. İşletmeler için birçok tedarikçi arasından uygun olanların seçimi oldukça zor ve bir o kadar da zaman ve para kaybıdır. En uygun ve doğru tedarikçiyi seçme, bir birlerini etkileyen ve birbiriyle çelişen birçok bileşen içerdiğinden oldukça karmaşık bir karar verme sürecidir. Bu karmaşık süreci yönetmek, birbiriyle çelişen kriterleri karşılaştırabilmek ve uygun tedarikçiyi seçebilmek için çok kriterli karar verme yöntemleri kullanılmaktadır. Literatürde tedarikçi seçim sürecinde kullanılan çok sayıda ve farklı çok kriterli karar verme (ÇKKV) yöntemi bulunmaktadır. Bu amaçla çalışmada bir traktör firmasında tedarikçi seçimi gerçekleştirmek amacıyla, en çok kullanılan çok kriterli karar verme tekniklerinden; MOORA, COPRAS ve hedef programlama teknikleri kullanılarak işletme içindeki uzman kişilerle ve literatürde yoğun olarak kullanılan üç temel grupta on beş kriter temel alınarak, işletmedeki beş tedarikçi firma değerlendirilmiş ve her üç yönteme göre en iyi tedarikçi/tedarikçiler belirlenmiştir.
\end{abstract}

Anahtar Kelimeler: Tedarikçi Seçimi, Çok Kriterli Karar Verme, Bulanık Analitik Hiyerarşi Prosesi, MOORA, COPRAS, Hedef Programlama.

\section{Selection of Suppliers with Multi Criteria Decision Making Methods in Tractor Manufacturing}

\begin{abstract}
Businesses have to work with many suppliers and make continuous decisions in order to continue their production activities. One of the most important decisions to be made for businesses is the selection of suppliers. Accurate, fast and low cost acquisition is important for the competitiveness of the enterprise. It is very difficult for companies to choose the most suitable supplier and it is a waste of time and money. Choosing the most appropriate and the right supplier is a very complex decision-making process because it contains many components that affect and conflict with each other. Multi-criteria decision-making methods are used to manage this complex process, compare conflicting criteria and select the appropriate supplier. In the literature, there are numerous and different multi-criteria decisionmaking methods used in supplier selection process. For this purpose, in order to realize supplier selection in a tractor company, one of the most used multi criteria decision making techniques; Five suppliers were evaluated using the MOORA, COPRAS and target
\end{abstract}

\footnotetext{
${ }^{1}$ Sorumlu Yazar: Sakarya Üniversitesi, Mühendislik Fakültesi, Endüstri Bölümü, Sakarya, Türkiye, ORCID: 0000-0002-9614-8119, tover@sakarya.edu.tr
} 
programming techniques, based on fifteen criteria in three main groups, which are used extensively in the literature, and the best suppliers / suppliers were determined according to all three methods.

Keywords: Supplier Choice, Multi Criteria Decision Making, Fuzzy Analytic Hierarchy Process, MOORA, COPRAS, Goal Programming.

\section{Giriş}

Tedarik zinciri, bir ürünün ilk kaynağından, nihai tüketicilerin talep ettiği son ürüne veya hizmete dönüştürülme sürecindeki tüm aşamaları, bu sürece değer katan üretici, tedarikçi ve lojistikte dahil olmak üzere tüm işlem ve katılımcılar grubu olarak tanımlanır. Tedarik zincirleri sürecindeki tüm malzemelerin, bilgilerin tedarikçiler ve müşterileri arasında karşılıklı işleyişinin etkin ve doğru bir şekilde sağlanmasına yönelik tüm görevlere Tedarik Zinciri Yönetimi denir. Tedarikçi ise; bazen satın alınacak mal veya hizmeti temin eden kişi, bazen bir işletme, kurum ya da kuruluşu ifade etmektedir. Doğru tedarikçilerle çalışmanın, işletmeler için iş hayatında oldukça önemli olduğu gerçekleştirilen çalışmalarla vurgulanmıştır. Günümüzün rekabetçi iş dünyasında, işletmeler kendileri için en iyi tedarikçiyi belirlemek isterler. Tedarikçi seçimi işletmelerin çalışma alanlarına göre değişim gösterebilmektedir. İşletmelerin, tedarikçilerinden yüksek beklentileri vardır. Bunlar; zamanında teslimat, kalite, fiyat uygunluğu, tekliflere cevap verebilme vb. gibi beklentilerdir. Ayrıca küreselleşmenin yarattı̆̆ı rekabetçi iş ortamları, yükselme isteği ve iş dünyasında yaşanan sorunlar, firmaları alternatif tedarikçi arama ve seçim sürecine yöneltmektedir.

Gerek hizmete gerekse imalata dayalı endüstrilerdeki birçok işletme, ekonomik verimliliği artırmak için en uygun tedarikçinin seçimine oldukça büyük önem vermektedir. İşletmelerin özellikle son yıllarda tedarikçilere daha fazla bağımlı hale gelmesi, işletmelerin hatalı verilen kararlar nedeniyle doğrudan veya dolaylı yaşadığı sonuçların etkisini daha da ağırlaştırmış, bu durumda tedarikçi seçimini, rekabet edebilirliği ve işletmenin kaderini belirler duruma gelmiştir[1]. Tedarikçi seçim süreci, süreklilik arz eden aranan tedarikçi/tedarikçilerin bulunması ile sona ermeyen aynı zamanda mevcut tedarikçilerin izlenmesi, geliştirilmesi ve gerektiğinde yeni tedarikçiler ile değiştirilmesi amaçlarını taşıyan bir süreçtir. Tedarikçi seçim/karar sürecinde doğal olarak birçok tedarikçi ve birçok karar kriteri bulunmaktadır. Uygun olan kriterlerin bulunması ve kriter karşılaştırmalarının tutarlı olması için bu süreçte bilimsel yöntemler kullanılmalıdır. Bunlara ilaveten geleneksel yöntemler bu seçim/karar sürecinde kişisel yargıya dayalı sonuç ürettiğinden, sayısal seçime dayalı araçlar, seçim sürecini daha rasyonel kılarak kişiye dayalı olmaktan çıkarabilir[2].

Tedarikçi değerlendirilme ve seçim süreci, hem nitel hem de nicel olabilen aynı zamanda da çok sayıda kriteri içeren tipik birçok kriterli karar verme (ÇKKV) problemi olarak görülebilir. Bu nedenle tedarikçi seçim süreci; sistematik ve rasyonel bir seçim modeli gerektirir. Tedarik zinciri literatüründe önerilen çok sayıda tedarikçi değerlendirme ve seçim yöntemi mevcuttur. Bu yöntemler sayesinde birçok kriter aynı anda değerlendirilebilmekte ve bu süreç içinde birden fazla kişi olaya dahil olabilmektedir. Çok kriterli karar verme yöntemleri sayesinde alternatifler daha verimli bir şekilde değerlendirebilmektedir.

Bu çalışmada, Sakarya ilinde traktör üretimi yapan bir fabrikada tedarikçi seçim problemine (karar verme sürecine) çözüm üretilmesi amaçlanmıştır. Tedarikçi değerlendirme ve seçim probleminin çözümünde çok kriterli karar verme tekniklerinden; Bulanık Analitik Hiyerarşi Prosesi, MOORA, COPRAS ve Hedef Programlama yöntemleri kullanılarak, yöneticilerin belirlenen kriterler kapsamında, kişisel yargıya dayalı olmayan ve rasyonel karar vermelerini sağlamak hedeflenmiştir.

\section{Literatür Araștırması}

Tedarikçi değerlendirme ve seçim süreci genellikle tedarik zinciri yönetiminin temel bileşeni ve çok kriterli karar verme problemi olarak görülmektedir. Karar verme ise, mevcut durumlar arasından mantıklı bir tercihin seçim süreci olarak değerlendirilmektedir. Tedarikçi değerlendirme ve seçim süreci, karar verme sürecinde çok fazla kriterin göz önünde bulundurulması gerektiği için son derece karmaşıktır. Bu nedenle 1960'lardan sonra birçok bilim adamı ve sektör çalışanının tedarikçi performansı ölçümü ve seçimi için kriterlerin analizine odaklandığı görülmektedir[2]. Tedarikçi seçim problemi ile ilgili birçok çalışmanın referans gösterdiği Dickson'ın çalışması tedarikçi seçimi ile ilgili 23 kriter ve bunların önemine odaklanmıştır. Çalışmada kalite; teslimat, performans geçmişi, talep politikaları, üretim tesisleri ve kapasite açısından son derece önemli görülürken, fiyat, teknik kapasite ve finansal durumun tedarikçi seçim sürecinde önemli bir yer tuttuğu vurgulanmıştır[3]. Satın alma süreci ile ilgili kişiler, tedarikçi seçiminde daima çok kriterli yaklaşımı göz önünde bulundurmaktadır[4]. Literatürde tedarikçi değerlendirme ve seçimi için çok kriterli karar verme yöntemleri kullanılarak çok sayıda çalışma yapılmıştır.

Analitik Hiyerarşi Prosesi (AHP), Analitik Ağ Prosesi (ANP), TOPSIS, MOORA, COPRAS, ELECTRE, PROMETHEE, VIKOR ve HEDEF PROGRAMLAMA metotları en yoğun kullanılan çok kriterli karar verme yöntemlerindendir. Örneğin Pak’ın çalışması bulanık mantık yaklaşımı ile mobilya sektöründe tedarikçi seçimine dayalıdır ve çalışmada bulanık TOPSIS, bulanık VIKOR ve bulanık PROMETHEE yöntemleri kullanılmıştır[5]. Ergül, bir gıda firmasında tedarikçi seçimi için Gri İlişkisel Analiz ve MOORA yöntemlerini kullanmış ve çalışma için 5 tedarikçi, 21 kriter belirlemiştir[6]. Tayyar'ın çalışması bulanık AHP ve bulanık TOPSİS yaklaşımı ile pet şişe tedarikçisi seçimine yöneliktir[7]. Durmaz ve diğerleri tedarikçi seçim probleminde Hedef Programlama ve MOORA yöntemlerini kullanarak en uygun tedarikçi seçimini gerçekleştirmişlerdir[8]. Çakır ve Kutlu Karabıyık 11 kriter ve 6 tedarikçi belirleyerek bütünleşik SWARA ve COPRAS yöntemi kullanarak bulut depolama hizmet sağlayıcılarının değerlendirmesini yaparak bir çalışma gerçekleştirmiştir[9]. Ömürbek ve Eren, gıda sektöründe faaliyet gösteren bir firmanın 2005-2014 yılları arasındaki performansını PROMETHEE, MOORA ve COPRAS yöntemleri ile yıllara göre sıralayarak bu yöntemlerle elde edilen sonuçları karşılaştırmıştır[10].

Kundakçı, MACBETH ve MULTI-MOORA yöntemlerine dayalı, birleşik çok kriterli karar verme yaklaşımı üzerine tedarikçi seçimi çalışması yapmıştır[11]. Madic ve diğerleri tedarikçi seçiminde COPRAS yöntemini kullanarak bir çalışma gerçekleştirmiştir[4]. Gencer ve diğerleri Hybrid Moora ve Fuzzy Algoritma ile özel eğitim ve rehabilitasyon merkezlerinin seçimi ile ilgili çalışma yapmışlardır[12]. 
Özdağoğlu, çok kriterli karar verme modellerinde normalizasyon sonuçlarının sonuçlara etkisini Copras yöntemi ile araştırmıştır[13]. Uğur, inşaat müdürü seçimi için çok kriterli karar verme yöntemlerinden MOORA yaklaşımını kullanarak; hem Oran Analizi tabanlı hem de Referans Noktası Teorisi esaslı hesaplamalar yapmış ve elde edilen sıralamaları karşılaştırmıştır[14]. Uygurtürk, çalışmasında internet bankacılığı için belirlenen kriterleri bulanık MOORA yöntemi ile değerlendirmiş, çalışma sonucunda uygun internet şubesi seçilmiştir[15].

Aksoy ve diğerleri AHP temelli Multi-Moora ve Copras yöntemi ile Türkiye kömür işletmelerinin performans değerlendirmesi üzerine çalışma gerçekleştirmişler, 7 kriter ve 8 kömür işletmesi belirleyerek performans değerlendirilmesi yapılmışlardır[16]. Aydın çalışmasında tedarikçi seçim problemi için bulanık çok kriterli karar verme ve hedef programlama yöntemlerini kullanarak savunma sanayii için bir uygulama gerçekleştirmiştir[17].

\section{Materyal ve Metot}

Literatürde değinildiği gibi tedarikçi seçim problemiyle ilgili çok sayıda çalışma ve yöntem mevcuttur. Tedarikçi seçimiyle ilgili gerçekleştirilen ilk çalışmalarda tek bir ana kriterin işletmeler üzerine etkisi ele alınırken yeni nesil çalışmalarda; satın alma, kalite ve lojistik gibi birçok ana kriterin kullanıldığı görülmektedir. Tedarikçi seçimi çalışmalarında yoğun kullanılan çok kriterli karar verme yöntemleri kullanımı ile ilgili en yeni eğilim, herhangi bir yöntemden kaynaklanabilecek eksiklikleri gidermek için iki veya daha fazla yöntemin birleştirilerek kullanımına yöneliktir[18]. Bu nedenle tedarikçi seçim problemlerinde birçok farklı yöntemin birlikte kullanıldığı görülmektedir.

$\mathrm{Bu}$ çalışmada kriterlerin puanlandırılması ve ağırlıklandırılmasında bulanık-AHP'den faydalanılmış, daha sonra tedarikçilerin değerlendirilmesi ve seçimi kısmında MOORA, COPRAS ve Hedef Programlama kullanılarak seçim yapılmıştır. Çalışmada; MOORA yöntemi, problemdeki tüm amaçları dikkate alması, alternatif ve amaçlara bütünsel olarak yaklaşması ve diğer çok kriterli karar verme tekniklerine göre çözümünün daha basit olması açısından tercih edilmiştir. COPRAS yöntemi ise, hem maksimize hem de minimize edilmek istenen kriterlerin değerlendirilmesine imkan sağlaması, bazı çok kriterli karar verme tekniklerinde negatif değerin dönüştürülmesi gerekirken bu yöntemde buna gereksinim duyulmaması ve hem nitel hem de nicel kriterleri değerlendirmeye izin vermesi bakımından çalışmaya dahil edilmiştir. Tüm bunlara ilaveten hedef programlamanın birden fazla amaca sahip modellerin çözümüne imkan sağlaması, çalışma sonucunda optimal sonuçlar vermesi ve birbiriyle zıt olan amaç fonksiyonlarının birlikte kullanılmasını sağlaması bir artı olarak düşünülmüştür.

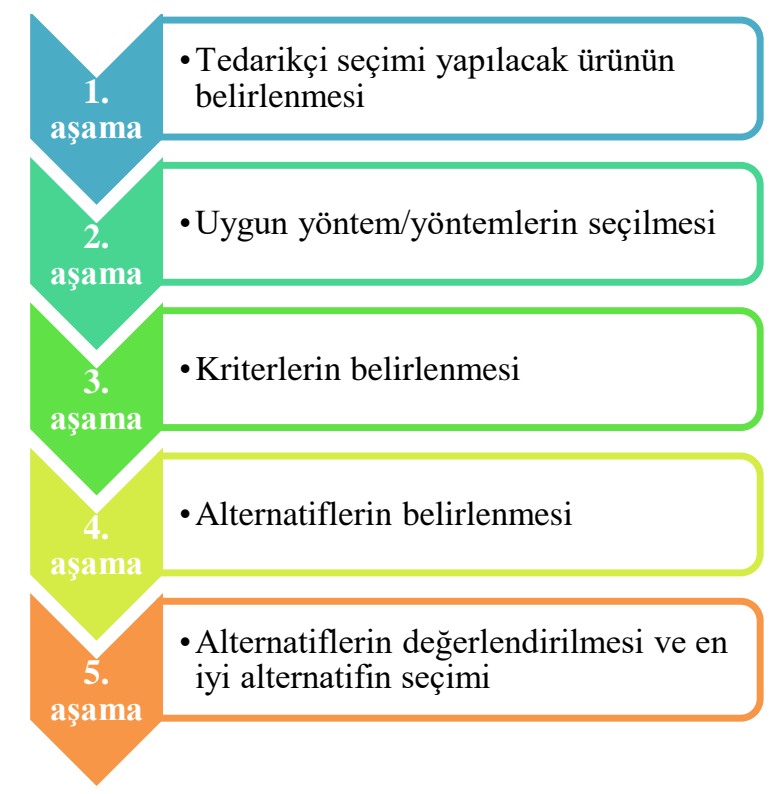

Şekil 1. Tedarikçi değerlendirme ve seçim süreci

Ayrıca son yıllarda tedarikçi seçimi çalışmalarında tek bir yöntem kullanılması durumunda ortaya çıkabilecek eksikliklerin ortadan kaldırılması amacıyla iki veya daha fazla yöntemin birleştirilerek kullanımı da çalışmada çoklu teknik kullanımını teşvik eden bir durumdur. Metodoloji kapsamında önce tedarikçi değerlendirme, seçim sürecinde izlenen akış (karar verme süreci) Şekil 1'de gösterilmiş ve sonrasında çalışmada kullanılan yöntemler; Bulanık-AHP, MOORA, COPRAS ve Hedef Programla hakkında kısa bilgiler verilmiştir.

\subsection{Bulanık Analitik Hiyerarşi Prosesi (AHP)}

Analitik Hiyerarşi Prosesi, literatürde yaygın kullanım bulmuş ve en iyi bilinen Çok Kriterli Karar Verme yaklaşımlarından biridir. Nitel ve nicel kriterlerin kullanımına uygun, anlaşılması ve uygulanması kolay bir yöntemdir. Karar verme sürecinde kişilerin tecrübe, bilgi ve sezgisini karara dâhil etmesine izin veren aynı zamanda ölçeklenebilir bir yöntemdir. Grup kararları için diğer yöntemlere göre daha uygundur[18, 19].

Fakat bazen karar verme durumundaki kişilerin düşüncelerini ifade etmede tam değerlerin kullanılması ve ikili karşılaştırma sürecindeki belirsizlik bakımından yetersizliği vurgulanmaktadır[20]. Bulanık AHP yöntemi tamda bu noktada kullanılabilen bir teknik olup, bulanı mantı ve AHP yöntemlerinin bir araya gelmesiyle oluşan melez bir yöntemdir. $\mathrm{Bu}$ bulanı olumlu ve olumsuz bakış açıları hesaplamalara dahil edebilmektedir. Bu tür problemleri çözmek amacıyla kullanılan yöntemlerden biri de 
Chang'in geliştirdiği Genişletilmiş Analiz Yöntemidir. Chang'in yönteminde, her bir ölçüt ve hedef için mertebe analizi yapılarak, her bir ölçüt için mertebe analiz değerleri elde edilir. Bu değer ve adımlar aşağıdaki şekilde gösterilir[21].

Adım 1; Ölçüt i’ye göre bulanık sentetik mertebe değerinin elde edilmesi:

$\mathrm{Si}_{\mathrm{i}}=\sum_{J=1}^{m} M_{g_{i}}^{j} \mathrm{x}\left[\sum_{i=1}^{n} \sum_{j=1}^{m} M_{g_{i}}^{j}\right]^{-1}$

Buradaki $\sum_{j=1}^{m} M_{g_{i}}^{j}$ değerini elde etmek amacıyla m mertebe analiz değerine bulanık toplama işlemi uygulanıp, daha sonra vektörün tersi çevrilerek aşağıdaki eşitlik hesaplanır.

$$
\left[\sum_{i=1}^{n} \sum_{j=1}^{m} M_{g_{i}}^{j}\right]^{-1}=\left(\frac{1}{\sum_{i=1}^{n} u_{i}}, \frac{1}{\sum_{i=1}^{n} m_{i}}, \frac{1}{\sum_{i=1}^{n} l_{i}}\right)
$$

Adım 2; $\mathrm{M}_{2}=\left(\mathrm{l}_{2}, \mathrm{~m}_{2}, \mathrm{u}_{2}\right) \geq \mathrm{M}_{1}=\left(\mathrm{l}_{1}, \mathrm{~m}_{1}, \mathrm{u}_{1}\right)$ 'in olabilirlik derecesi şu şekilde tanımlanır;

$$
V\left(M_{2} \geq M_{1}\right) \neq \begin{array}{cc}
1 & m_{2} \geq m_{1} \\
0 & l_{1} \geq u_{2} \\
\frac{l_{1}-u_{2}}{\left(m_{2}-u_{2}\right)-\left(m_{1}-l_{1}\right)} & \text { diğer }
\end{array}
$$

Olabilirlik dereceleri $\mathrm{V}\left(\mathrm{M}_{2} \geq \mathrm{M}_{1}\right)^{\prime}$ ler için matris oluşturulur.

Adım 3; Bir dışbükey bulanık sayı için k derece dışbükey bulanık sayılardan daha büyük olması olasılığı $\mathrm{M}_{\mathrm{i}}$ aşağıdaki eşitlik ile tanımlanabilir. $\mathrm{i}=1,2,3, \ldots . ., \mathrm{k}$

$$
\mathrm{V}\left(\mathrm{M} \geq \mathrm{M}_{1}, \mathrm{M} 2, \mathrm{Mk}\right)=\mathrm{v}\left[\mathrm{M} \geq \mathrm{M}_{1 \text { ve }} \mathrm{M} \geq \mathrm{M}_{2} \text { ve } \mathrm{M} \geq \mathrm{M}_{\mathrm{k}}\right] \quad=\operatorname{minv} \mathrm{M} \geq \mathrm{M}_{1}, \mathrm{i}=1,2,3, \ldots ., \mathrm{k}
$$

$\mathrm{Bu}$ karşılaştırmalar sonucunda çıkan değerlerin minimumu $\mathrm{k}=1,2, \ldots . ., \mathrm{n} ; \mathrm{k} \neq \mathrm{i}$ alınarak (d'( $\left.\left.A_{\mathrm{i}}\right)\right)$ hesaplanır. Bu işlem tüm satırlar için devam ettirilerek hesaplama yapılır. Daha sonra ağırlık vektörü aşağıdaki eşitlik kullanılarak hesaplanır.

$$
W^{\prime}=\left(d^{\prime}\left(A_{1}\right), d^{\prime}\left(A_{2}\right), \ldots, d^{\prime}\left(A_{n}\right)\right)^{T}
$$

Burada $A_{i}(i=1,2, \ldots, n) n$ elemandan oluşmaktadır.

Adım 4; Normalleştirme uygulanarak, normalleştirilmiş ağırlık vektörü elde edilir. Burada W, bulanık olmayan bir sayıyı ifade etmektedir.

$$
\mathrm{W}=\left(\mathrm{d}\left(\mathrm{A}_{1}\right), \mathrm{d}\left(\mathrm{A}_{2}\right), \ldots, \mathrm{d}\left(\mathrm{A}_{\mathrm{n}}\right)^{\mathrm{T}}\right.
$$

Aşağıda Tablo 1'de İkili karşılaştırmaların yapılabilmesi amacıyla kullanılan bulanık sayılar görülmektedir.

Tablo 1. Chang yöntemine göre BAHP'de kullanılan ölçek/ikili karşılaştırma yapılırken kullanılan önem dereceleri [4, 9]

\begin{tabular}{l|c|c}
\hline \multicolumn{1}{c|}{ Sözel Önem Derecesi } & Bulanık Ölçek & Karşılık Ölçek \\
\hline Eşit Önemli & $(1,1,1)$ & $(1 / 1,1 / 1,1 / 1)$ \\
\hline Daha Fazla Önemli & $(1,3,5)$ & $(1 / 5,1 / 3,1 / 1)$ \\
\hline Kuvvetli Derecede Önemli & $(3,5,7)$ & $(1 / 7,1 / 5,1 / 3)$ \\
\hline Çok Kuvvetli Derece Önemli & $(5,7,9)$ & $(1 / 9,1 / 7,1 / 5)$ \\
\hline Tamamıyla Önemli & $(7,9,9)$ & $(1 / 9,1 / 9,1 / 7)$ \\
\hline
\end{tabular}

\subsection{COPRAS Yöntemi (Complex Proportional Assessment/Karmaşık Oransal Değerlendirme)}

COPRAS yöntemi, kriterlerin önem ve fayda ölçütlerini göz önünde bulundurarak alternatifleri sıralanması ve değerlendirilmesinde kullanılır. Çok kriterli karar vermede kullanılan yöntem, maksimum ve minimum kriter değerlerini kullanarak karmaşık kriterler ve çok sayıda alternatif içeren problemlere uygulanabilir. Bu özellikleri literatürde birçok farklı alanda uygulamasını mümkün kılmıştır. COPRAS yöntemine göre alternatiflerin önem ve önceliği oransal olarak sıralanması genellikle yedi adımda gerçekleşir.

Adım 1; X, başlangıç matrisinin oluşturulması. $X_{i j}$, $i$ 'inci alternatifin $j$ ’inci kriteridir. Alternatif sayısı, $i=1, \ldots . . \mathrm{m}$; kriter sayısı, $j=1, \ldots .$. n'e kadardır

$$
\mathrm{X}=\left[X_{i j}\right]_{m x n}=\begin{array}{cccc}
X_{11} & X_{12} & \ldots & X_{1 n} \\
X_{21} & X_{22} & \ldots & X_{2 n} \\
\ldots & \ldots & \ldots & \ldots . \\
X_{m 1} & X_{m 2} & \ldots & X_{m n}
\end{array}
$$

Adım 2; Normalleştirme işleminin gerçekleştirilmesi / D, normalleştirilmiş karar matrisinin oluşturulması. Normalleştirme, ele alınan alternatiflerin performanslarını karşılaştırabilmek için yapılır[2]. Normalleştirme için aşağıdaki formül kullanılır. Bu işlem sonucunda " $D$ " karar matrisi elde edilir. 
$x_{i j} * \frac{x_{i j}}{\sum_{i=1}^{m} x_{i j}}$

$X_{i j}$, i'inci alternatifin j'inci kritere göre performansını gösterirken, $X_{i j} *$ normalleştirilmiş değeri gösterir.

Adım 3; Ağırlıklandırılmış karar matrisi oluşturma; (3. 9) nolu eşitlik kullanılarak her bir kriter için belirlenen $w_{i j}$ ağırlık değerleri kullanılarak $\mathrm{d}_{i j}$ denklemi oluşturulur. ( $\mathrm{w}_{j}$ : $\mathrm{j}$. değerlendirme kriterinin önem düzeyi; $\mathrm{j}=1,2, \ldots, \mathrm{n}$ ). Sütunların bulanık AHP'de hesaplanan ağırlıklarla çarpılmasıyla elde edilir.

$$
\mathrm{D}=\mathrm{d}_{\mathrm{ij}}=x_{i j} * \mathrm{w}_{\mathrm{j}} \quad \mathrm{w}_{\mathrm{j}}=\mathrm{ağıl} \text { lık }
$$

Adım 4; Faydalı ve faydasız ölçütleri hesaplama; Faydalı ve faydasız ölçütlerden kasıt, faydalı ölçütün hedefe ulaşmada daha yüksek değerlere sahip olmayı ifade ederken, faydası ölçütün hedefe ulaşmada daha düşük değere sahip olduğunu ifade etmesidir. Denklem (3. 10) ve (3. 11) kullanılarak faydalı ve faydasız ölçütler hesaplanır. Faydalı ölçüt, $S_{i}^{+}$, faydasız ölçüt, $S_{i}^{-}$ile gösterilmiştir.

$$
\begin{array}{ll}
S_{i}^{+} ;=\sum_{j=1}^{k} d i j & \mathrm{j}=1,2, \ldots, \mathrm{k} \text { faydalı ölçütler } \\
S_{i}^{-}=\sum_{j=k+1}^{n} d_{i j} & \mathrm{i}=\mathrm{k}+1, \mathrm{k}+2, . . \mathrm{n} \text { faydasız ölçütler }
\end{array}
$$

Bu sayede, yapilan hesaplamalar ek olarak kontrol edilebilir.

Adım 5; Her alternatif için $Q_{i}$ ile gösterilen göreceli önem derecelerinin hesaplanması; Gerçekleştirilen işlemler sonucu en yüksek önem değerine sahip olan alternatif performansı en yüksek alternatif olarak belirlenir. Her bir alternatif için $Q_{i}$ değeri eşitlik (3. 12) numaralı eşitlik kullanılarak hesaplanır.

$$
Q_{i}=s_{i}^{+}+\frac{\sum_{i=1}^{m} s_{i}^{-}}{s_{i}^{-} \cdot \Sigma_{i=1}^{m} \frac{1}{s_{i}^{\bar{T}}}}
$$

Adım 6; En yüksek göreceli $Q_{i}$ (önem değeri) değeri bulunur. Böylece öncelikli alternatif belirlenmiş olur. Eşitlik (3. 13) numaralı denklem yardımıyla en yükssek göreceli değer hesaplanır.

$$
Q_{\max }=\text { en büyük }\left\{Q_{i}\right\} \forall \mathrm{i}=1,2, \ldots, \mathrm{m}
$$

Adım 7; Her bir alternatif göz önünde bulundurularak $\mathrm{P}_{\mathrm{i}}$ değeri hesaplanır; Alternatifler için performans indeksinin hesaplanmasına dayalıdır. $P_{i}$ indeks değeri eşitlik (3. 14) yardımıyla hesaplanır.

$$
P_{i=\frac{Q i}{Q \max }} \cdot 100 \%
$$

Yukarıda adımları açıklanan COPRAS yöntemi, alternatiflerin değerlendirilmesi ve en verimli olanın seçimi kolaylıkla uygulanabilmektedir[4, 9, 10, 16, 21].

\section{3. MOORA Yöntemi}

Literatürde yeni olan MOORA yönteminin çözümü diğer çok kriterli karar verme yöntemlerine göre daha basittir. Yöntemin; Tam Çarpım Yöntemi, Referans Nokta Yaklaşımı, Oran Yöntemi ve Çoklu-MOORA olmak üzere dört versiyonu vardır. MOORA yöntemi problemdeki tüm amaçları dikkate alarak, alternatif ve amaçlara bütünsel olarak yaklaşır. Yöntemin ilk ve temel adımı standart karar matrisi oluşturmaya dayalıdır. Öncelikle alternatiflere ve kriterlere ait veriler kullanılarak bir karar matrisi oluşturulur. Matriste; i: alternatifi; j: kriter ya da ölçütü; m: toplam alternatif sayısını; n: toplam ölçüt ya da kriter sayısını ve xij: i. alternatifin j. ölçüt açısından performans ölçüm değerini göstermektedir[11].

\subsubsection{MOORA-Oran Yöntemi}

Oran yöntemi yaklaşımı, herhangi bir amaca yönelik alternatiflerin etkisinin karşılaştırılması durumda ortaya çıkan performanstı/faydadır (performans/fayda; bu amaçla ilgili tüm alternatiflerin temsil edilebilmesi). Oran yöntemi yaklaşımının çözümünde $\mathrm{X} \_\mathrm{ij}^{*}$ değeri hesaplanmalıdır. $\mathrm{X} \_\mathrm{ij} *$ değerini hesaplamada (3.15) numaralı formül kullanılır. Bu sayede normalleştirme işlemi gerçekleştirilir.

$$
x_{i j} *=\frac{x_{i j}}{\sqrt{\sum_{i=1}^{m} x_{i j}^{2}}}
$$

$x i j *$, i. alternatifin $\mathrm{j}$. amacına göre normalleştirilmiş performans değerini göstermektedir. Bu değer 0,1 aralığında olabileceği gibi, 1,1 aralı̆ı̆ında da olabilir. Bu sayede hazırlanan tabloda amaçlar maksimum veya minimum olarak belirlenir ve toplanırlar. Toplam maksimum amaç değerlerinden toplam minimum amaç değeri çıkartılır.

$\mathrm{j}=1,2, . ., \mathrm{g}$ maksimize edilecek amaçlar,

$\mathrm{j}=\mathrm{g}+1, \mathrm{~g}+2, . ., \mathrm{n}$ minimize edilecek amaçlar olacak şekilde i alternatifinin tüm amaçlar için normalleştirilmiş hali (3. 16 ) yardımı ile hesaplanır. yi *'ler sıralanarak işlem tamamlanır[6].

$$
y_{i}^{*}=\sum_{j=1}^{g} x_{i j}^{*}-\sum_{j=g+1}^{n} x_{i j}^{*}
$$

\subsubsection{Referans Nokta Yaklaşımı}


Referans nokta yaklaşımında, oran yöntemine ilaveten her amaç için maksimum amaç referans noktaları $\left(r_{j}\right)$ belirlenir. Bu referans noktaları eğer amaç, maksimize etmek ise maksimum noktalar, minimize etmek ise minimum noktalardır. Eşitlik (3.17) kullanılarak, alternatiflerin her bir amaca (referans noktasına) olan uzaklıkları bulunur.

$$
d_{i j}=\left|r_{j}-x_{i j}^{*}\right|
$$

Alternatiflerin sıralamasında (3.18) numaralı eşitlik kullanılır. Böylece her alternatifin performansları bulunarak $\left(P_{i}\right)$ alternatifler büyükten küçüğe sıralanması sağlanır. En yüksek performansa sahip alternatif en iyi seçenek olarak belirlenir.

$$
P_{i}=\min _{i}\left(\max _{j} d_{i j}\right)
$$

\subsubsection{Tam Çarpım Yöntemi}

Tam çarpım yöntemi, Brauers ve Zavadskas tarafından 2010 yılında geliştirmiştir. MOORA-Tam çarpım yönteminde aşağıdaki eşitlikler kullanılır.

$$
\begin{aligned}
& U_{i}=A_{i} / B_{i} \\
& A_{i}=\prod_{j=1}^{g} x_{i j}
\end{aligned}
$$

m, alternatif sayısını, j maksimizasyon/fayda ölçütlerinin sayısını, ifade etmektedir ve i=1,..,m’ye kadardır.

$$
B i=\prod_{g+1}^{i} x_{i j}
$$

Burada Ai maksimum olması amaçlanan tüm kriterlerde i. kriterin aldığı değerlerin çarpımı iken, Bi minimum olması amaçlanan tüm kriterlerde i kriterin aldığı değerlerin çarpımı demektir. $U_{i}$ alternatiflerin aldığı değerleri göstermekte ve $U_{i}$ değerleri büyükten küçüğe doğru sıralandığında birinci sıradaki alternatif en uygun alternatif olarak değerlendirilmektedir[6].

\subsection{4. Çoklu-MOORA Yaklaşımı}

Çoklu-MOORA yaklaşımında amaç; oran yöntemi, referans nokta yaklaşımı ve tam çarpım yönteminden elde edilen sonuçlar arasında baskın olanını belirlemeye yani öncelikli seçenekleri belirleyerek karar vericiye destek olmaya dayalıdır.

\section{4. Hedef Programlama Yöntemi}

Hedef programlama, temeli doğrusal programlamaya dayanan çok amaçlı bir programlama yöntemidir. Bu yöntemde karar vericiler her bir amaç için ulaşmak istedikleri bir hedef değer belirler. Minimum sapmaya ulaşan çözüm, sonuç olarak belirlenir. Hedef programlamada amaç karar vericilerin belirlediği tüm kısıtları sağlayan ve mümkün olduğunca tüm hedeflere ulaşan bir çözüm bulmaya dayalıdır. Hedef programlama birçok farklı alanlarda kullanılan bir yöntemdir. Yöntem temelde bir amaç fonksiyonu ve kısıtlardan oluşmaktadır[22]. Aşağıda hedef programlama için genel formüller (3.22 - 3.24) görülmektedir.

Burada amaç fonksiyonu; Belirlenen hedeflerden $d_{i}^{+}$ve $d_{i}^{-}$sapmaların minimize edilmesi ile ilgilidir[18].

$\operatorname{MinZ}=\sum_{i=1}^{k}\left(d_{i}^{+}+d_{i}^{-}\right)$

$\sum_{j=1}^{n} k_{i j} y_{j}+d_{i}^{+}+d_{i}^{n}=l_{i}$

Kısitlar;

$d_{i}^{+}+d_{i}^{n}=0$

$x_{j}, d_{i}^{+}, d_{i}^{-} \geq 0$

$i=1, \ldots \ldots, k \quad j=1, \ldots \ldots, n$

Değişkenler;

$y_{j} ; j$. Karar değişkeni

$k_{i j} ; i$. hedefin j. karar değişkeni katsayısı

$l_{i} ; i$. hedef için ulaşılmak istenen değer

$d_{i}+; i$. hedefin pozitif sapmas1

$d_{i^{-}} ; i$. Hedefin negatif sapmas 1

\section{Uygulama}

Tedarikçi değerlendirme ve seçim süreci kapsamında (Şekil 1) uygulama adımları gerçekleştirilmiştir. Çalışmada öncelikle işletmede üretilen ürünler uzmanlarca değerlendirilerek (işletme için stratejik olduğu düşünülen) 9 ürün belirlenmiş, seçilen 9 ürünün 2016 ve 2017 yıllarının 9 aylık üretim miktarları sistemden çekilmiştir. Bu ürünlerin toplam üretimdeki oran değerleri elde edilmiş, “ $a$ ” ürününün en yüksek orana sahip ürün olduğu belirlenmiştir.

Kriterlerin puanlandırılması ve ağırlıklandırılması için bulanık AHP, tedarikçilerin değerlendirilmesi ve seçiminde MOORA, COPRAS ve Hedef Programlama kullanılmış, her yöntem için de ayrı ayrı hesaplamalar yapılmış ve çıkan sonuçlar karşılaştırılarak yorumlanmıştır. İşletme içindeki uzmanlar ve literatürden hareketle kriterler belirlenmiş (Tablo 2), “ $a$ ” ürününün alt bileşenleri baz alınarak, kendi bileşenleri içindeki oran ve toplam alım içindeki oran yüzdeleri hesaplanmış ve satın alma mühendisi ile görüşülerek alternatif tedarikçiler belirlenmiştir. Alternatif tedarikçilerin değerlendirilerek en iyi tedarikçinin seçimi aşamasının alt süreci aşağıda adım adım ele alınmış ve çıkan sonuçlar yorumlanmıştır.

\subsection{Bulanık-AHP Yöntemi ile Kriterlerin Puanlandırılması ve Ağırlıklandırılması}


İşletme içindeki uzmanlar ve literatürden hareketle belirlenen kriterler, aşağıda Tablo 2'de görülebilir. Kriterler; satın alma, kalite ve lojistik olmak üzere üç ana grup ve toplam 15 alt kriterden oluşmaktadır.

Tablo 2. Kriter tablosu

\begin{tabular}{|c|c|}
\hline \multirow{6}{*}{ Satın Alma } & $\mathrm{K} 1=$ Teklif Verme Hizı \\
\hline & K2=Maliyet Analizli Çalışabilme Yeteneği \\
\hline & K3=İşbirliği Yaklaşım Ve Hızı \\
\hline & K4=Mevcut Ve Yeni Ürünlerde Tasarım Ve Geliştirme İle Uygulama Hızı \\
\hline & K5=Yenilikleri Takip Etme, Üretim Ve Tasarım Yeteneklerine Yansıtma \\
\hline & K6=Belgelendirme \\
\hline \multirow{5}{*}{ Kalite } & K7=PPM Puan 1 \\
\hline & K8=Rapor Yoğunluğu \\
\hline & K9=Kalite Takdir Puanı \\
\hline & K10=Numune Performans1 \\
\hline & K11=Servis İadesi \\
\hline \multirow{4}{*}{ Lojistik } & K12=Sevkiyat Performans 1 \\
\hline & K13=Hat Performans 1 \\
\hline & K14=Ambalaj, Etiket, Nakliye Uygunluğu \\
\hline & K15=Ulaşılabilirlik Ve İletişim Kolaylığı \\
\hline
\end{tabular}

Metodoloji içinde Tablo 1.'de verilen Bulanık ölçeklendirme puan tablosu[6] dikkate alınarak kriterler ağırlıklandırılmış, Adım 1'de satın alma, kalite, lojistik ve planlama bölümlerindeki uzmanlarca puanlandırılan kriterlerin aritmetik ortalaması alınarak Tablo 3.'de görülen ikili karşılaştırma matrisi oluşturulmuştur.

Tablo 3. İkili karşılaştırma matrisi

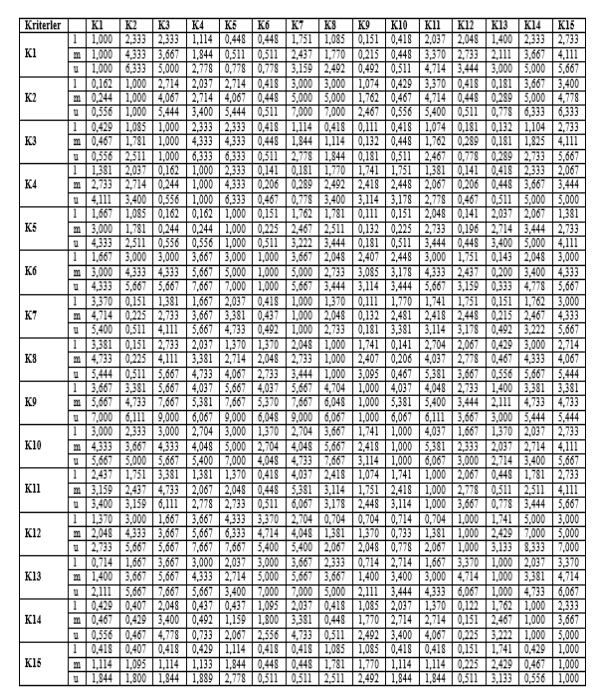

Adım 2'de kriterlerin sentetik değerleri (3. 1 ve 3.2) numaralı eşitliğe göre hesaplanmış ve Tablo 4'de verilmiştir. 
European Journal of Science and Technology

Tablo 4. Sentetik değerler tablosu

\begin{tabular}{c|l|l|l}
\hline Kriterler & \multicolumn{1}{|c|}{$\mathbf{l}$} & \multicolumn{1}{|c}{$\mathbf{m}$} & \multicolumn{1}{l}{} \\
\hline$K 1$ & 0,028 & 0,055 & 0,113 \\
\hline$K 2$ & 0,036 & 0,068 & 0,132 \\
\hline$K 3$ & 0,019 & 0,041 & 0,086 \\
\hline$K 4$ & 0,024 & 0,049 & 0,100 \\
\hline$K 5$ & 0,020 & 0,040 & 0,083 \\
\hline$K 6$ & 0,046 & 0,088 & 0,167 \\
\hline$K 7$ & 0,028 & 0,055 & 0,110 \\
\hline$K 8$ & 0,035 & 0,066 & 0,130 \\
\hline$K 9$ & 0,073 & 0,130 & 0,223 \\
\hline$K 10$ & 0,047 & 0,091 & 0,175 \\
\hline$K 11$ & 0,036 & 0,065 & 0,120 \\
\hline$K 12$ & 0,044 & 0,087 & 0,167 \\
\hline$K 13$ & 0,045 & 0,091 & 0,178 \\
\hline$K 14$ & 0,022 & 0,044 & 0,090 \\
\hline$K 15$ & 0,013 & 0,029 & 0,063 \\
\hline
\end{tabular}

Adım 3'de (3. 3) numaralı formülle kriter ağırlıkları hesaplanmış ve Tablo 5'de verilmiştir.

Ağırlıklar bulunurken her kriter için minimum değer seçilmiş, seçilen minimum değeri toplam min. değerine bölünerek her kriter için ağırlıklar hesaplanmıştır.

Tablo 5. Kriter ă̆ırlıkları hesaplama

\begin{tabular}{|c|c|c|c|c|c|c|c|c|c|c|c|c|c|c|c|c|c|}
\hline & K1 & K2 & K3 & K4 & K5 & K6 & K7 & K8 & K9 & K10 & K11 & K12 & K13 & K14 & K15 & MIN & AĞIRLIK \\
\hline K1 & & 0,863 & 1,000 & 1,000 & 1,000 & 0,671 & 1,000 & 0,876 & 0,345 & 0,649 & 0,888 & 0,690 & 0,656 & 1,000 & 1,000 & 0,345 & 0,053 \\
\hline K2 & 1,000 & & 1,000 & 1,000 & 1,000 & 0,808 & 1,000 & 1,000 & 0,483 & 0,784 & 1,000 & 0,824 & 0,789 & 1,000 & 1,000 & 0,483 & 0,074 \\
\hline K3 & 0,799 & 0,652 & & 0,887 & 1,000 & 0,458 & 0,799 & 0,667 & 0,126 & 0,438 & 0,672 & 0,483 & 0,450 & 0,950 & 1,000 & 0,126 & 0,019 \\
\hline K4 & 0,914 & 0,772 & 1,000 & & 1,000 & 0,577 & 0,914 & 0,786 & 0,247 & 0,556 & 0,795 & 0,599 & 0,565 & 1,000 & 1,000 & 0,247 & 0,038 \\
\hline K5 & 0,782 & 0,632 & 0,989 & 0,873 & & 0,434 & 0,782 & 0,647 & 0,097 & 0,414 & 0,651 & 0,460 & 0,427 & 0,937 & 1,000 & 0,097 & 0,015 \\
\hline K6 & 1,000 & 1,000 & 1,000 & 1,000 & 1,000 & & 1,000 & 1,000 & 0,688 & 0,976 & 1,000 & 1,000 & 0,977 & 1,000 & 1,000 & 0,688 & 0,106 \\
\hline K7 & 0,999 & 0,857 & 1,000 & 1,000 & 1,000 & 0,660 & & 0,871 & 0,326 & 0,637 & 0,883 & 0,680 & 0,645 & 1,000 & 1,000 & 0,326 & 0,050 \\
\hline K8 & 1,000 & 0,987 & 1,000 & 1,000 & 1,000 & 0,794 & 1,000 & & 0,468 & 0,771 & 1,000 & 0,811 & 0,775 & 1,000 & 1,000 & 0,468 & 0,072 \\
\hline K9 & 1,000 & 1,000 & 1,000 & 1,000 & 1,000 & 1,000 & 1,000 & 1,000 & & 1,000 & 1,000 & 1,000 & 1,000 & 1,000 & 1,000 & 1,000 & 0,154 \\
\hline K10 & 1,000 & 1,000 & 1,000 & 1,000 & 1,000 & 1,000 & 1,000 & 1,000 & 0,722 & & 1,000 & 1,000 & 1,000 & 1,000 & 1,000 & 0,722 & 0,111 \\
\hline K11 & 1,000 & 0,970 & 1,000 & 1,000 & 1,000 & 0,763 & 1,000 & 0,985 & 0,418 & 0,738 & & 0,782 & 0,744 & 1,000 & 1,000 & 0,418 & 0,064 \\
\hline K12 & 1,000 & 1,000 & 1,000 & 1,000 & 1,000 & 0,987 & 1,000 & 1,000 & 0,680 & 0,963 & 1,000 & & 0,965 & 1,000 & 1,000 & 0,680 & 0,105 \\
\hline K13 & 1,000 & 1,000 & 1,000 & 1,000 & 1,000 & 1,000 & 1,000 & 1,000 & 0,727 & 0,999 & 1,000 & 1,000 & & 1,000 & 1,000 & 0,727 & 0,112 \\
\hline K14 & 0,845 & 0,695 & 1,000 & 0,936 & 1,000 & 0,496 & 0,845 & 0,711 & 0,158 & 0,475 & 0,717 & 0,520 & 0,486 & & 1,000 & 0,158 & 0,024 \\
\hline K15 & 0,568 & 0,411 & 0,786 & 0,661 & 0,793 & 0,217 & 0,568 & 0,427 & 0,000 & 0,202 & 0,422 & 0,250 & 0,220 & 0,728 & & 0,000 & 0,000 \\
\hline TOPLAM & & & & & & & & & & & & & & & & 6,484 & 1,000 \\
\hline
\end{tabular}

Adım 4'de normalleştirme uygulanmış, normalleştirilmiş ağırlık vektörü elde edilmiştir. Yukarıda Tablo 5'de her bir kriterin ağırlığı son sütün da/AĞIRLIK başlığı altında görülmektedir. Bu adımda (3. 6) numaralı eşitlik kullanılmıştır. Bulanık AHP'nin adımları tamamlandıktan sonra, uzman kişilerce tedarikçilerin kriterlere göre puanlandırılması gerçekleştirilmiş, tedarikçi puanlandırma matrisi hazırlanmış ve Tablo 6'da verilmiştir. Satın alma tarafından belirlenen 5 tedarikçi arasından en iyisinin seçilmesi amacıyla tedarikçiler kriterlere göre 1'den 5'e kadar puanlandırılmıştır. Belirlenen tedarikçiler; T1, T2, T3, T4 ve T5 olarak gösterilmiştir. 
Tablo 6. Tedarikçi puanlandırma matrisi

\begin{tabular}{|c|c|c|c|c|c|}
\hline Kriterler & T1 & $\mathbf{T} 2$ & T3 & T4 & T5 \\
\hline$K 1$ & 3,000 & 3,000 & 4,000 & 1,000 & 4,000 \\
\hline$K 2$ & 5,000 & 4,000 & 4,000 & 2,000 & 3,000 \\
\hline$K 3$ & 4,000 & 4,000 & 4,000 & 1,000 & 4,000 \\
\hline$K 4$ & 5,000 & 4,000 & 5,000 & 2,000 & 4,000 \\
\hline$K 5$ & 5,000 & 4,000 & 5,000 & 2,000 & 3,000 \\
\hline$K 6$ & 5,000 & 3,000 & 4,000 & 1,000 & 2,000 \\
\hline$K 7$ & 4,000 & 4,000 & 4,000 & 1,000 & 3,000 \\
\hline$K 8$ & 4,000 & 3,000 & 1,000 & 2,000 & 2,000 \\
\hline K9 & 5,000 & 5,000 & 4,000 & 1,000 & 4,000 \\
\hline$K 10$ & 3,000 & 4,000 & 4,000 & 1,000 & 5,000 \\
\hline K11 & 4,000 & 1,000 & 3,000 & 3,000 & 4,000 \\
\hline$K 12$ & 4,000 & 4,000 & 4,000 & 2,000 & 5,000 \\
\hline$K 13$ & 5,000 & 5,000 & 5,000 & 2,000 & 5,000 \\
\hline$K 14$ & 4,000 & 4,000 & 4,000 & 3,000 & 3,000 \\
\hline K15 & 4,000 & 4,000 & 4,000 & 3,000 & 4,000 \\
\hline
\end{tabular}

\subsection{COPRAS Yönteminin Uygulanması}

Adım 1; Başlangıç matrisinin oluşturulması. Metodoloji kısmında (3.7)'de verilen bakış açısı ve Tablo 6 başlangıç matrisi olarak kullanılmıştır.

Adım 2; Normalizasyon işlemi (3.8) numaralı eşitlik kullanılarak gerçekleştirilmiş ve aşağıda Tablo 7'de gösterilmiş̧ir.

Tablo 7. Normalizasyon işlemi sonuç tablosu

\begin{tabular}{l|r|l|l|l|l}
\hline & T1 & \multicolumn{1}{|c|}{ T2 } & \multicolumn{1}{|c|}{ T3 } & \multicolumn{1}{|c}{ T4 } & T5 \\
\hline$K 1$ & 0,200 & 0,200 & 0,267 & 0,067 & 0,267 \\
\hline$K 2$ & 0,278 & 0,222 & 0,222 & 0,111 & 0,167 \\
\hline$K 3$ & 0,235 & 0,235 & 0,235 & 0,059 & 0,235 \\
\hline$K 4$ & 0,250 & 0,200 & 0,250 & 0,100 & 0,200 \\
\hline$K 5$ & 0,263 & 0,211 & 0,263 & 0,105 & 0,158 \\
\hline$K 6$ & 0,333 & 0,200 & 0,267 & 0,067 & 0,133 \\
\hline$K 7$ & 0,250 & 0,250 & 0,250 & 0,063 & 0,188 \\
\hline$K 8$ & 0,333 & 0,250 & 0,083 & 0,167 & 0,167 \\
\hline$K 9$ & 0,263 & 0,263 & 0,211 & 0,053 & 0,211 \\
\hline$K 10$ & 0,176 & 0,235 & 0,235 & 0,059 & 0,294 \\
\hline$K 11$ & 0,267 & 0,067 & 0,200 & 0,200 & 0,267 \\
\hline$K 12$ & 0,211 & 0,211 & 0,211 & 0,105 & 0,263 \\
\hline$K 13$ & 0,227 & 0,227 & 0,227 & 0,091 & 0,227 \\
\hline$K 14$ & 0,222 & 0,222 & 0,222 & 0,167 & 0,167 \\
\hline$K 15$ & 0,211 & 0,211 & 0,211 & 0,158 & 0,211 \\
\hline
\end{tabular}

Adım 3: Ağırlıklandırılmış normalizasyon (3. 9) numaralı eşitlik kullanılarak, sütunların bulanık AHP ile elde edilen ağırlıklarla çarpılmasıyla hesaplanır. Bu değerler Tablo 8'de görülmektedir. 
European Journal of Science and Technology

Tablo 8. Ağırlıklandırılmış normalizasyon

\begin{tabular}{|c|c|c|c|c|c|c|}
\hline & T1 & $\mathbf{T 2}$ & T3 & T4 & T5 & \\
\hline$K 1$ & 0,011 & 0,011 & 0,014 & 0,004 & 0,014 & $\max$ \\
\hline$K 2$ & 0,021 & 0,016 & 0,016 & 0,008 & 0,012 & $\max$ \\
\hline$K 3$ & 0,004 & 0,004 & 0,004 & 0,001 & 0,004 & $\max$ \\
\hline$K 4$ & 0,010 & 0,008 & 0,010 & 0,004 & 0,008 & $\max$ \\
\hline$K 5$ & 0,004 & 0,003 & 0,004 & 0,002 & 0,002 & $\max$ \\
\hline K6 & 0,035 & 0,021 & 0,028 & 0,007 & 0,014 & $\max$ \\
\hline$K 7$ & 0,013 & 0,013 & 0,013 & 0,003 & 0,009 & $\max$ \\
\hline$K 8$ & 0,024 & 0,018 & 0,006 & 0,012 & 0,012 & $\max$ \\
\hline K9 & 0,041 & 0,041 & 0,032 & 0,008 & 0,032 & $\max$ \\
\hline$K 10$ & 0,020 & 0,026 & 0,026 & 0,007 & 0,033 & $\max$ \\
\hline$K 11$ & 0,017 & 0,004 & 0,013 & 0,013 & 0,017 & $\min$ \\
\hline$K 12$ & 0,022 & 0,022 & 0,022 & 0,011 & 0,028 & $\max$ \\
\hline$K 13$ & 0,025 & 0,025 & 0,025 & 0,010 & 0,025 & $\max$ \\
\hline$K 14$ & 0,005 & 0,005 & 0,005 & 0,004 & 0,004 & $\max$ \\
\hline$K 15$ & 0,000 & 0,000 & 0,000 & 0,000 & 0,000 & $\max$ \\
\hline TOPLAM & 0,251 & 0,218 & 0,219 & 0,093 & 0,216 & \\
\hline
\end{tabular}

Adım 4;Faydalı ve faydasız ölçütler (3. 10 ve 3. 11), Adım 5'deki göreceli önem derecelerinin hesaplanması (3.12), Adım 6'da en yüksek göreceli $Q_{i}$ değeri bulunması (3.13) ve Adım 7'de $P_{i}$ değeri (3.14) kullanılarak hesaplanmış ve Tablo 9'da elde edilen değerler gösterilmiştir. Burada, Sıralama sütununda tedarikçilerin performans sıralaması görülebilir.

Tablo 9 Tedarikçiler için $\mathrm{Sj}^{+}, \mathrm{Sj}^{-}, 1 / \mathrm{Sj}^{-}$, Qi,Pi değerleri

\begin{tabular}{c|r|r|l|l|l|c}
\hline & $\mathbf{S j +}$ & $\mathbf{S j -}$ & $\mathbf{1 / S j -}$ & $\mathbf{Q i}$ & $\mathbf{P i}$ & Suralama \\
\hline$T 1$ & 0,234 & 0,017 & 58,594 & 0,241 & 99,280 & 2 \\
\hline$T 2$ & 0,214 & 0,004 & 234,375 & 0,243 & 100,000 & 1 \\
\hline$T 3$ & 0,207 & 0,013 & 78,125 & 0,217 & 89,093 & 3 \\
\hline$T 4$ & 0,080 & 0,013 & 78,125 & 0,090 & 37,095 & 5 \\
\hline$T 5$ & 0,199 & 0,017 & 58,594 & 0,206 & 84,737 & 4 \\
\hline Toplam & & 0,064 & 507,813 & & & \\
\hline
\end{tabular}

\section{3. MOORA Yöntemlerinin Uygulanması}

Çok kriterli karar verme yöntemleri arasında yeni bir yöntem sayılan MOORA yöntemi; Tam çarpım, Referans nokta yaklaşımı, Oran ve bunların sonuçlarını sentezleyen Çoklu MOORA olmak üzere 4 farklı yöntemden oluşmaktadır. MOORA yöntemi içindeki farklılıkları sentezleyen çoklu-MOORA analizi, karar vericiye baskın karakterin bulunması konusunda yardımcı olur.

\subsubsection{Oran Yöntemi}

Adım 1; Başlangıç matrisinin oluşturulması amacıyla daha önce uzmanlarca tedarikçilerin puanlandırılması ile oluşturulan Tablo 6 kullanılır.

Adım 2; Karar Matrisinin Normalleştirilmesi (3.15) numaralı eşitlik kullanılarak gerçekleştirilir. Tablo 10'da normalleştirilmiş matris değerleri görülmektedir. 
Tablo 10. Normalleştirilmiş sonuç matrisi

\begin{tabular}{l|l|l|l|l|l}
\hline & T1 & T2 & T3 & T4 & T5 \\
\hline$K 1$ & 0,420 & 0,420 & 0,560 & 0,140 & 0,560 \\
\hline$K 2$ & 0,598 & 0,478 & 0,478 & 0,239 & 0,359 \\
\hline$K 3$ & 0,496 & 0,496 & 0,496 & 0,124 & 0,496 \\
\hline$K 4$ & 0,539 & 0,431 & 0,539 & 0,216 & 0,431 \\
\hline$K 5$ & 0,563 & 0,450 & 0,563 & 0,225 & 0,338 \\
\hline$K 6$ & 0,674 & 0,405 & 0,539 & 0,135 & 0,270 \\
\hline$K 7$ & 0,525 & 0,525 & 0,525 & 0,131 & 0,394 \\
\hline$K 8$ & 0,686 & 0,514 & 0,171 & 0,343 & 0,343 \\
\hline$K 9$ & 0,549 & 0,549 & 0,439 & 0,110 & 0,439 \\
\hline$K 10$ & 0,367 & 0,489 & 0,489 & 0,122 & 0,611 \\
\hline$K 11$ & 0,560 & 0,140 & 0,420 & 0,420 & 0,560 \\
\hline$K 12$ & 0,456 & 0,456 & 0,456 & 0,228 & 0,570 \\
\hline$K 13$ & 0,490 & 0,490 & 0,490 & 0,196 & 0,490 \\
\hline$K 14$ & 0,492 & 0,492 & 0,492 & 0,369 & 0,369 \\
\hline$K 15$ & 0,468 & 0,468 & 0,468 & 0,351 & 0,468 \\
\hline
\end{tabular}

Adım 3; Ağırlıklandırılmış normalizasyonun elde edilmesi için Bulanık AHP ile elde edilen ağırlıklar normalizasyon sonuç matrisiyle çarpılarak ağırlıklandırılmış normalizasyon matrisi elde edilir. Bu adımın sonucu Tablo 11'de görülebilir.

Tablo 11. A ğırlıklandırllmış Normalizasyon Matrisi

\begin{tabular}{l|l|l|l|l|l}
\hline & T1 & T2 & T3 & T4 & T5 \\
\hline$K 1$ & 0,022 & 0,022 & 0,030 & 0,007 & 0,030 \\
\hline$K 2$ & 0,044 & 0,035 & 0,035 & 0,018 & 0,027 \\
\hline$K 3$ & 0,009 & 0,009 & 0,009 & 0,002 & 0,009 \\
\hline$K 4$ & 0,020 & 0,016 & 0,020 & 0,008 & 0,016 \\
\hline$K 5$ & 0,008 & 0,007 & 0,008 & 0,003 & 0,005 \\
\hline$K 6$ & 0,071 & 0,043 & 0,057 & 0,014 & 0,029 \\
\hline$K 7$ & 0,026 & 0,026 & 0,026 & 0,007 & 0,020 \\
\hline$K 8$ & 0,049 & 0,037 & 0,012 & 0,025 & 0,025 \\
\hline$K 9$ & 0,085 & 0,085 & 0,068 & 0,017 & 0,068 \\
\hline$K 10$ & 0,041 & 0,054 & 0,054 & 0,014 & 0,068 \\
\hline$K 11$ & 0,036 & 0,009 & 0,027 & 0,027 & 0,036 \\
\hline$K 12$ & 0,048 & 0,048 & 0,048 & 0,024 & 0,060 \\
\hline$K 13$ & 0,055 & 0,055 & 0,055 & 0,022 & 0,055 \\
\hline$K 14$ & 0,012 & 0,012 & 0,012 & 0,009 & 0,009 \\
\hline$K 15$ & 0,000 & 0,000 & 0,000 & 0,000 & 0,000 \\
\hline
\end{tabular}

Adım 4; Tedarikçilerin sıralanması amacıyla (3.16) nolu eşitlik kullanılarak Tablo 12 elde edilir. Tabloda tedarikçilerin sıralaması görülebilir.

Tablo 12. Tedarikçi sıralanması

\begin{tabular}{l|l|l}
\hline Tedarikçi & $\mathbf{y}^{*}$ & Oran \\
\hline$T 1$ & 0,456 & $\mathbf{1}$ \\
\hline$T 2$ & 0,441 & $\mathbf{2}$ \\
\hline$T 3$ & 0,409 & $\mathbf{3}$ \\
\hline$T 4$ & 0,143 & $\mathbf{5}$ \\
\hline$T 5$ & 0,383 & $\mathbf{4}$ \\
\hline
\end{tabular}

\subsubsection{Referans Nokta Yaklaşımı}

Adım 1; Başlangıç matrisinin oluşturulması amacıyla Tablo 6 kullanılır (oran yönteminde kullanılan başlangıç matrisi).

Adım 2; Normalizasyon işlemi sonucu, oran yöntemindeki Tablo 10 ile aynıdır. 
Adım 3; Bu adımda oran metodunda olduğu gibidir ve Tablo 11 kullanılır.

Adım 4; Kriterlerin referans değerinin elde edilmesi işlemi minimum, maksimum yöntemine göre belirlenir. Kriter maximizasyon amaçlı ise kriterin aldığı değerlerden en yüksek olanı referans değeri olarak belirlenir. Kriter minimizasyon amaçlı ise kriterin aldığ değerlerden en küçük olanı referans değeri olarak belirlenir. Bu aşama sonucunda Tablo 13 oluşturlmuştur.

Tablo 13. Referans Değeri Tablosu

\begin{tabular}{l|l|l|l|l|l|l|l}
\hline & T1 & T2 & T3 & T4 & T5 & Referans & \\
\hline$K 1$ & 0,022 & 0,022 & 0,030 & 0,007 & 0,030 & 0,030 & $\max$ \\
\hline$K 2$ & 0,044 & 0,035 & 0,035 & 0,018 & 0,027 & 0,044 & $\max$ \\
\hline$K 3$ & 0,009 & 0,009 & 0,009 & 0,002 & 0,009 & 0,009 & $\max$ \\
\hline$K 4$ & 0,020 & 0,016 & 0,020 & 0,008 & 0,016 & 0,020 & $\max$ \\
\hline$K 5$ & 0,008 & 0,007 & 0,008 & 0,003 & 0,005 & 0,008 & $\max$ \\
\hline$K 6$ & 0,071 & 0,043 & 0,057 & 0,014 & 0,029 & 0,071 & $\max$ \\
\hline$K 7$ & 0,026 & 0,026 & 0,026 & 0,007 & 0,020 & 0,026 & $\max$ \\
\hline$K 8$ & 0,049 & 0,037 & 0,012 & 0,025 & 0,025 & 0,049 & $\max$ \\
\hline$K 9$ & 0,085 & 0,085 & 0,068 & 0,017 & 0,068 & 0,085 & $\max$ \\
\hline$K 10$ & 0,041 & 0,054 & 0,054 & 0,014 & 0,068 & 0,068 & $\max$ \\
\hline$K 11$ & 0,036 & 0,009 & 0,027 & 0,027 & 0,036 & 0,009 & $\min$ \\
\hline$K 12$ & 0,048 & 0,048 & 0,048 & 0,024 & 0,060 & 0,060 & $\max$ \\
\hline$K 13$ & 0,055 & 0,055 & 0,055 & 0,022 & 0,055 & 0,055 & $\max$ \\
\hline$K 14$ & 0,012 & 0,012 & 0,012 & 0,009 & 0,009 & 0,012 & $\max$ \\
\hline$K 15$ & 0,000 & 0,000 & 0,000 & 0,000 & 0,000 & 0,000 & $\max$ \\
\hline
\end{tabular}

Adım 5; Kriterlerin referans noktasına uzaklıkları (3.17) numaralı eşitlik kullanılarak hesaplanmış ve Tablo 14'de bu değerler verilmiştir.

Tablo 14. Referans noktası matrisi hesaplama

\begin{tabular}{l|c|c|c|c|c}
\hline & T1 & T2 & T3 & T4 & T5 \\
\hline$K 1$ & 0,007 & 0,007 & 0,000 & 0,022 & 0,000 \\
\hline$K 2$ & 0,000 & 0,009 & 0,009 & 0,027 & 0,018 \\
\hline$K 3$ & 0,000 & 0,000 & 0,000 & 0,007 & 0,000 \\
\hline$K 4$ & 0,000 & 0,004 & 0,000 & 0,012 & 0,004 \\
\hline$K 5$ & 0,000 & 0,002 & 0,000 & 0,005 & 0,003 \\
\hline$K 6$ & 0,000 & 0,029 & 0,014 & 0,057 & 0,043 \\
\hline$K 7$ & 0,000 & 0,000 & 0,000 & 0,020 & 0,007 \\
\hline$K 8$ & 0,000 & 0,012 & 0,037 & 0,025 & 0,025 \\
\hline$K 9$ & 0,000 & 0,000 & 0,017 & 0,068 & 0,017 \\
\hline$K 10$ & 0,027 & 0,014 & 0,014 & 0,054 & 0,000 \\
\hline$K 11$ & 0,027 & 0,000 & 0,018 & 0,018 & 0,027 \\
\hline$K 12$ & 0,012 & 0,012 & 0,012 & 0,036 & 0,000 \\
\hline$K 13$ & 0,000 & 0,000 & 0,000 & 0,033 & 0,000 \\
\hline$K 14$ & 0,000 & 0,000 & 0,000 & 0,003 & 0,003 \\
\hline$K 15$ & 0,000 & 0,000 & 0,000 & 0,000 & 0,000 \\
\hline
\end{tabular}

Adım 6; Tedarikçilerin sıralanması, (3.18) numaralı eşitlik kullanılarak elde edilmiş ve sonuç Tablo 15'de gösterilmiştir. Tabloda tedarikçilerin sıralaması görülebilir.

Tablo 15. Tedarikçi sıralanması

\begin{tabular}{l|l|l|l|l|l}
\hline & $\mathbf{T 1}$ & $\mathbf{T 2}$ & $\mathbf{T 3}$ & $\mathbf{T 4}$ & $\mathbf{T 5}$ \\
\hline $\max$ & 0,027 & 0,029 & 0,037 & 0,068 & 0,043 \\
\hline min siralama & $\mathbf{1}$ & $\mathbf{2}$ & $\mathbf{3}$ & $\mathbf{5}$ & $\mathbf{4}$ \\
\hline
\end{tabular}

\subsubsection{Tam Çarpım Yöntemi}

Adım 1; Başlangıç matrisinin oluşturulması aşamasında Tablo 6 kullanılmıştır. 
Adım 2; $U_{i}$ değerlerinin bulunması amacıyla (3.19, 3.20 ve 3.21) numaralı eşitlikler kullanılmış ve elde edilen değerler Tablo 16 'da verilmiştir.

Tablo 16. U değerlerinin hesaplanmast

\begin{tabular}{|l|c|c|c|c|c|c|}
\hline & T1 & T2 & T3 & T4 & T5 & \\
\hline K1 & 3,000 & 3,000 & 4,000 & 1,000 & 4,000 & $\max$ \\
\hline K2 & 5,000 & 4,000 & 4,000 & 2,000 & 3,000 & $\max$ \\
\hline F1:K1XK2 & 15,000 & 12,000 & 16,000 & 2,000 & 12,000 & \\
\hline K3 & 4,000 & 4,000 & 4,000 & 1,000 & 4,000 & $\max$ \\
\hline F2:F1XK3 & 60,000 & 48,000 & 64,000 & 2,000 & 48,000 & \\
\hline K4 & 5,000 & 4,000 & 5,000 & 2,000 & 4,000 & $\max$ \\
\hline F3:F2XK4 & 300,000 & 192,000 & 320,000 & 4,000 & 192,000 & \\
\hline K5 & 5,000 & 4,000 & 5,000 & 2,000 & 3,000 & $\max$ \\
\hline F4:F3XK5 & 1500,000 & 768,000 & 1600,000 & 8,000 & 576,000 & \\
\hline K6 & 5,000 & 3,000 & 4,000 & 1,000 & 2,000 & $\max$ \\
\hline F5:F4XK6 & 7500,000 & 2304,000 & 6400,000 & 8,000 & 1152,000 & \\
\hline K7 & 4,000 & 4,000 & 4,000 & 1,000 & 3,000 & $\max$ \\
\hline F6:F5XK7 & 30000,000 & 9216,000 & 25600,000 & 8,000 & 3456,000 & \\
\hline K8 & 4,000 & 3,000 & 1,000 & 2,000 & 2,000 & $\max$ \\
\hline F7:F6XK8 & 120000,000 & 27648,000 & 25600,000 & 16,000 & 6912,000 & \\
\hline K9 & 5,000 & 5,000 & 4,000 & 1,000 & 4,000 & $\max$ \\
\hline F8:F7XK9 & 600000,000 & 138240,000 & 102400,000 & 16,000 & 27648,000 & \\
\hline K10 & 3,000 & 4,000 & 4,000 & 1,000 & 5,000 & $\max$ \\
\hline F9:F8*K10 & 1800000,000 & 552960,000 & 409600,000 & 16,000 & 138240,000 & \\
\hline K11 & 4,000 & 1,000 & 3,000 & 3,000 & 4,000 & $\min$ \\
\hline F10:F9/K11 & 450000,000 & 552960,000 & 136533,333 & 5,333 & 34560,000 & \\
\hline K12 & 4,000 & 4,000 & 4,000 & 2,000 & 5,000 & $\max$ \\
\hline F11:F10*K12 & 1800000,000 & 2211840,000 & 546133,333 & 10,667 & 172800,000 & \\
\hline K13 & 5,000 & 5,000 & 5,000 & 2,000 & 5,000 & $\max$ \\
\hline F12:F11*K13 & 9000000,000 & 11059200,000 & 2730666,667 & 21,333 & 864000,000 & \\
\hline K14 & 4,000 & 4,000 & 4,000 & 3,000 & 3,000 & $\max$ \\
\hline F13:F12*K14 & 36000000,000 & 44236800,000 & 10922666,667 & 64,000 & 2592000,000 & \\
\hline K15 & 4,000 & 4,000 & 4,000 & 3,000 & 4,000 & $\max$ \\
\hline F14:F13*K15 & 144000000,000 & 176947200,000 & 43690666,667 & 192,000 & 10368000,000 & \\
\hline & & & & & & \\
\hline
\end{tabular}

Adım 3: Tedarikçilerin sıralanması, Tablo 16'dan elde edilen sonuca göre gerçekleştirilmiş ve Tablo 17'de verilmiştir. Tablo 17'de tedarikçilerin sıralaması görülebilir.

Tablo 17. Tedarikçi sıralanması

\begin{tabular}{l|c|c|c|l|l}
\hline & T1 & T2 & T3 & T4 & T5 \\
\hline Dĕ̆ger & 144000000 & 176947200 & 43690666,67 & 192 & 10368000 \\
\hline Stralama & $\mathbf{2}$ & $\mathbf{1}$ & $\mathbf{3}$ & $\mathbf{5}$ & $\mathbf{4}$ \\
\hline
\end{tabular}

\subsection{4. Çoklu-MOORA Yaklaşımı}

Oran, tam çarpım yöntemi, referans nokta yaklaşımı sonuçları değerlendirilerek, her bir yöntem sonucunda ortaya çıkan sıralamalardan baskınlık durumu göz önüne alınarak sıralama yapılır. Bu sıralamanın sonucu Tablo 18'de verilmiştir. Baskınlık durumları değerlendirildiğinde en iyi tedarikçinin T1 olduğu ve sıralamanın T2, T3, T5, T4 şeklinde devam ettiği görülebilir.

Tablo 18. Multi-Moora analizi tablosu

\begin{tabular}{l|c|c|c|c}
\hline & Oran Yön. & Referans Nokta Yaklaşımı & Tam Çarpım Yön. & Çoklu-MOORA \\
\hline$T 1$ & 1 & 1 & 2 & 1 \\
\hline$T 2$ & 2 & 2 & 1 & 2 \\
\hline$T 3$ & 3 & 3 & 3 & 3 \\
\hline$T 4$ & 5 & 5 & 5 & 5 \\
\hline$T 5$ & 4 & 4 & 4 & 4 \\
\hline
\end{tabular}

\section{4. Hedef Programlama Yönteminin Uygulanması}

Aşağıda çözüm aşamasında kullanılacak olan parametreler, değişkenler ve kısıtlar tanımlanmıştır. Problemin çözümünde LINGO 15 yazılımı kullanılmıştır. Parametre olarak tedarikçiler; T1=x1, T2=x2, T3=x3, T4=x4 ve T5=x5 olarak, K1sıtlar; K1=d1, K2=d2, K3=d3, $\mathrm{K} 4=\mathrm{d} 4, \mathrm{~K} 5=\mathrm{d} 5, \mathrm{~K} 6=\mathrm{d} 6, \mathrm{~K} 7=\mathrm{d} 7, \mathrm{~K} 8=\mathrm{d} 8, \mathrm{~K} 9=\mathrm{d} 9, \mathrm{~K} 10=\mathrm{d} 10, \mathrm{~K} 11=\mathrm{d} 11$, K12=d12, K13=d13, K14=d14 ve K15=d15 olarak tanımlanmıştır.

Karar değişkenleri; $\mathrm{di}^{+}$: i. hedefin pozitif sapması ve di-: i. hedefin negatif sapması olarak belirlenmiştir.

Matematiksel Modelde, Bulanık AHP'den elde edilen ağırlıklar amaç fonksiyonuna dahil edilmiştir.

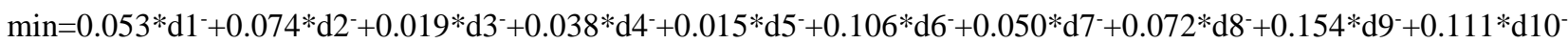
$+0.064 * \mathrm{~d} 11^{+}+0.105^{*} \mathrm{~d} 12^{-}+0.112^{*} \mathrm{~d} 13^{-}+0.024 * \mathrm{~d} 14^{-}+0.000^{*} \mathrm{~d} 15^{-}$

Maksimizasyon amaçlı kriterler için belirlenen hedef 5 olarak alınırken, minimizasyon amaçlı hedefler için belirlenen hedef 1 olarak kabul edilmiştir. Buna göre oluşturulan modele her bir kısıt (kriter) dahil edilmiştir. Aşağıda 1. Kısıt için ayrıntı verilmiştir. Diğer kısıtlarda 


\section{European Journal of Science and Technology}

burada gösterildiği şekilde hesaplanmıştır. Burada tedarikçileri simgeleyen x1, x2, x3, x4 ve x5'in önündeki çarpan değerler tedarikçi puanlandırma matrisinden (Tablo 6'dan) elde edilen değerlerdir.

1.Teklif verme hızı kısıtı: Tedarikçi puanlaması yapılırken oluşturulan matristen elde edilen katsayılarla oluşturulmuştur. Maxmizasyonu sağlayan kısıt olduğu için belirlenen hedef 5'dir

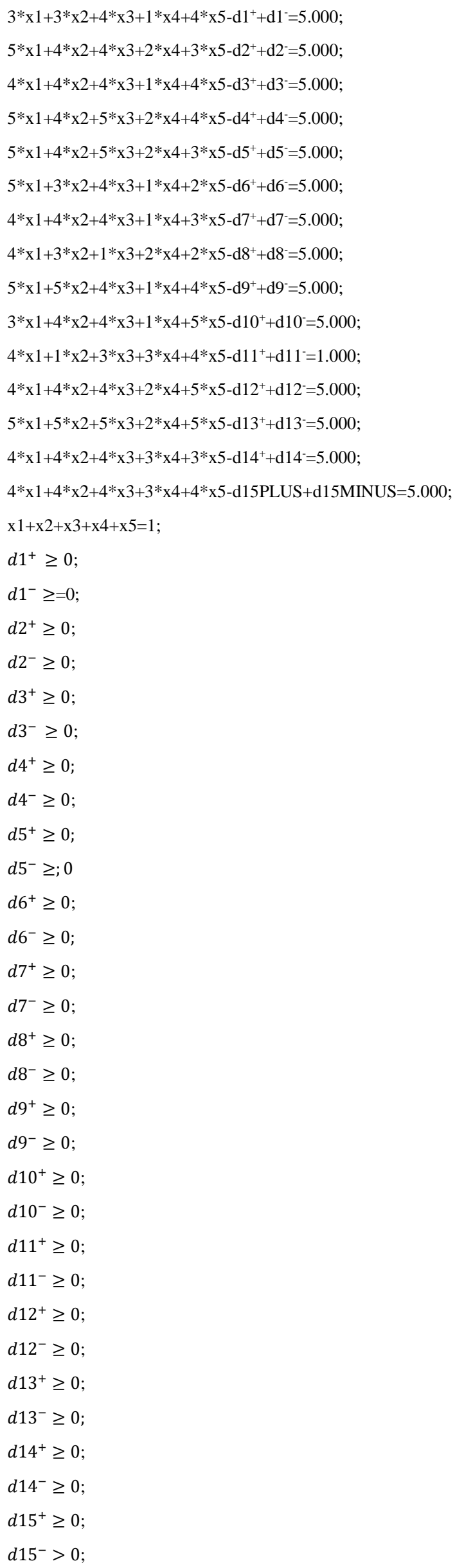


$x i \in\{0,1\}$

Modelin Lingo'da çözümü sonucunda x1'in en iyi tedarikçi olduğu sonucuna varılmıştır.

\section{Sonuç}

Müşteri isteklerinin hızlı değiştiği rekabet ortamında, işletmelerin varlıklarını sürdürebilmek için başarımlarını artırmaları bir zorunluluk haline gelmiştir. Başarım artırmada en önemli bileşenlerden biri de işletmelerin sahip olduğu tedarik zincirleridir. Bu sebeple tedarik zincirini oluşturan unsurların başarısı, doğrudan işletmelerin başarısını etkilemektedir. Tedarik zincirinin en önemli halkalarından biri olan tedarikçilerin seçimi de, dinamik süreçler ve artan tedarikçi sayısı nedeniyle önemli bir karar problemi haline gelmiştir. Çünkü doğru tedarikçi seçimi, işletmelerin rekabet yeteneğini artırma ve maliyetleri azaltmada, önemli bir etkiye sahiptir. Bu bağlamda da tedarikçi seçimi yapılırken işletmelerin doğru kriterleri kullanması, problemlerini net bir şekilde ifade etmesi ve kişiye bağlı, sezgiye dayalı yöntemler yerine bilimsel yöntemlerden faydalanması önemlidir.

$\mathrm{Bu}$ amaçla çalışmada mevcut bir karar problemini çözmek için, çok kriterli karar verme tekniklerinden bulanık-AHP, MOORA, COPRAS ve hedef programlama yöntemleri kullanılmıştır. Traktör üretimi yapan bir işletmede önce tedarikçileri değerlendirmede kullanılacak kriterler belirlenerek, bunların önem seviyeleri (ağılıkları) bulanık AHP ile tespit edilmiştir. Bir sonraki adımda da işletmedeki uzmanlarla belirlenen alternatif tedarikçiler MOORA yöntemleri, COPRAS ve Hedef programlama kullanılarak değerlendirilmiştir.

\section{Kaynakça}

[1] Dragan, S., Kovačević, I., Simić, S., "50 Years of Fuzzy Set Theory and Models for Supplier Assessment and Selection: A Literature Review", Journal of Applied Logic, Volume 24, November 2017, 85-96.

[2] Lu, D., "Fundamentals of Supply Chain Management", Ventus Publishing, 2011, ISBN 978-87-7681-798-5.

[3] Dickson, G.W., "An Analysis of Vendor Selection System and Decisions”, J. Purch. 2 (1) (1966) 5-17.

[4] Madic, M., Markovic, D., Petrovic, G., Radovanovic, M., "Application of Copras Method for Supplier Selection", The Fifth International Conference Transport and Logistics, 2014.

[5] Pak, N., "Bulanık Mantık Yaklaşımı ile Mobilya Sektöründe Tedarikçi Seçimi”, Yüksek Lisans Tezi, Sakarya Üniversitesi, Fen Bilimleri Enstitüsü, Sakarya, 2015.

[6] Ergül, Ö., "Gri İlişkisel Analiz ve MOORA Yöntemleriyle Tedarikçi Seçimi ve Bir İşletmede Uygulaması", Yüksek Lisans Tezi, Kocaeli Üniversitesi, Fen Bilimleri Enstitüsü, Kocaeli, 2015.

[7] Tayyar, N., "Pet Şişe Tedarikçisi Seçiminde Bulanık AHP ve Bulanık TOPSíS Yaklaşımı", Süleyman Demirel Üniversitesi, İktisadi ve İdari Bilimler Fakültesi Dergisi,17,351-371,2012.

[8] Durmaz E.B, Akagündüz, E., Şahin R., "Tedarikçi Seçim Probleminde Hedef Programlama ve MOORA Yöntemi:Uygulama Çalışması", Gazi Üniversitesi, İktisadi ve İdari Bilimler Fakültesi Dergisi,19/3,1021-1044,2017.

[9] Çakır, E., Kutlu Karabıyık, B., "Bütünleşik SWARA - COPRAS Yöntemi Kullanarak Bulut Depolama Hizmet Sağlayıcılarının Değerlendirilmesi” Bilişim Teknolojileri Dergisi, Cilt: 10, Sayı: 4, Ekim 2017.

[10]Ömürbek, N., Eren, H., "Promethee, Moora ve Copras Yöntemleri ile Oran Analizi Sonuçlarının Değerlendirilmesi: Bir Uygulama" Mehmet Akif Ersoy Üniversitesi Sosyal Bilimler Enstitüsü Dergisi, Cilt: 8, Sayı: 16, Eylül 2016, S.174-187.

[11]Kundakc1, N., "Combıned Multi-Criteria Decision Making Approach Based on MACBETH and Multi-MOORA Methods", Dergipark, 4(1),017-026, 2016.

[12]Ozcelik, G., Aydogan, E. K., Gencer, C., “A Hybrid Moora-Fuzzy Algorithm for Special Education and Rehabilitaion Center Selection", Journal of Military and Information Science, Volume: 2, P: 53-62, 2014.

[13]Özdağoğlu, A., "Çok Ölçütlü Karar Verme Modellerinde Normalizasyon Tekniklerinin Sonuçlara Etkisi:Copras Örneği”, Eskişehir Osmangazi Üniversitesi İ̈FF Dergisi, 8(2),229-252, 2013.

[14]Uğur, L.O., "MOORA Optimizasyon Yaklaşımı ile İnşaat Proje Müdürü Seçimi: Çok Kriterli bir Karar Verme Uygulaması", Politeknik dergisi, 20(3), 717-723,2017.

[15]Uygurtürk, H., "Bankaların İnternet Şubelerinin Bulanık Moora Yöntemi ile Değerlendirilmesi”, Uluslararası Yönetim İktisat ve İşletme Dergisi, Cilt 11, Sayı 25, 2015.

[16]Aksoy E., Ömürberk, N., Karaatlı,M., “AHP Temelli Multimoora ve COPRAS Yöntemi ile Türkiye Kömür İsletmeleri’nin Performans Değerlendirmesi”, Hacettepe Üniversitesi İktisadi ve İdari Bilimler Fakültesi Dergisi, 33,1-28, 2015.

[17]Aydın, Y., "Tedarikçi Seçim Probleminin Bulanık Çok Ölçütlü Karar Verme ve Hedef Programla Yöntemleri ile Çözümü: Savunma Sanayisinde bir Uygulama”,Yüksek Lisans Tezi, Kırıkkale Üniversitesi, Fen Bilimleri Enstitüsü, Kırıkkake, 2017.

[18]Velasquez, M.; Hester, P. T., "An Analysis of Multi-Criteria Decision Making Methods" International Journal of Operations Research Vol. 10, No. 2, 56-66 (2013).

[19]Saaty R.W., "The Analytic Hierarchy process-what it is and how it is used", Mathematical Modelling, Vol 9, Issue 3-5, 1987, pp 161-176.

[20]Saaty T.L., "Decision Making with the Analytic Hierarchy Process,” Int. J. Serv. Sci., Vol. 1, No. 1, pp. 83-98, 2008.

[21]Ajalli, M., Azimi, H., Balani, A. M., Rezaei, M., "Application of Fuzzy AHP and COPRAS to Solve the Supplier Selection Problems", Vol 6, No 3 (2017), International Journal of Supply Chain Management (IJSCM).

[22]Alağaş, H. M., Mermi, Ö. S., Kızıltaş, Ş., Eren, T., Hamurcu, M., "Analitik Hiyerarşi Prosesi ve Hedef Programlama Yöntemi ile Reklam Stratejisi Seçimi: Mobilya Firması Örneği”, Published in 5th International Symposium on Innovative Technologies in Engineering and Science 29-30 September 2017. 